\title{
Phytochemical screening and antibacterial activity of rosmarinus officinalis l. against Escherichia coli. local isolates
}

\author{
Saima Johar ${ }^{1 *}$, Shazia Irfan ${ }^{2}$, Shehnaz Sher Ahmed ${ }^{2}$, Rukhsana Jabeen ${ }^{2}$ \\ ${ }^{1}$ Department of Plant Sciences, Sardar Bahadur Khan Women University, Quetta, Pakistan \\ ${ }^{2}$ Department of Plant Sciences, SBK Women's University Quetta Pakistan \\ *Corresponding author E-mail: saimajohar90@yahoo.com
}

Copyright $\odot 2015$ Saima Johar et al. This is an open access article distributed under the Creative Commons Attribution License, which permits unrestricted use, distribution, and reproduction in any medium, provided the original work is properly cited.

\begin{abstract}
Rosmarinus officinalis is a medicinal plant which belongs to family Lamiaceae. It is an evergreen bush. It was analyzed for its phytochemical constitution and antibacterial activity. For this purpose flowers, leaves and stem of aqueous and methanolic extracts were used. The tests of phytochemical screening showed that flavonoids, terpenoids, reducing sugar and saponins were present in different concentrations, while tannin was absent in all parts of plant. The antibacterial activity was determined against E. coli with different concentrations (i-e $0.5 \mathrm{gm}, 1 \mathrm{gm}$ and $1.5 \mathrm{gm}$ ) kept for 24 hours and 48 hours duration. The results showed that the highest mean inhibition zone was observed in the methanolic extracts of leaves $1.5 \mathrm{gm}$ kept for 48 hours $(28.6 \pm 4.261 \mathrm{~mm})$.In the stem the methanolic extracts showed the highest inhibition zone with the concentration of $1.5 \mathrm{gm}(13.4 \pm 1.624 \mathrm{~mm})$ kept for 24 hours. In the flower the highest inhibition zone in methanolic extracts was observed in $1 \mathrm{gm}(25.4 \pm 2.416 \mathrm{~mm}) \mathrm{kept}$ for 48 hours. In the aqueous extracts the highest inhibition zone values were $(17.6 \pm 4.029 \mathrm{~mm}, 15.8 \pm 2.993 \mathrm{~mm}, 14.4 \pm 2.33 \mathrm{~mm})$ for stem, flower and leaves respectively.
\end{abstract}

Keywords: Aqueous Extract. Methonolic Extract; Concentrations; Phytochemical; Antibacterial.

\section{Introduction}

Rosmarinus officinalis is a medicinal plant it belongs to the family Lamiaceae [2]. It is an evergreen, perennial bush. Its height is 1-2 meters long [32]. It is a much branched shrub. The branches are cylindrical and the bark of this plant is pale brown fibrous. The leaves of this plant are evergreen opposite, 1-1 inch long, blunt at both ends, densely covered with white stellate hairs. The flower of this plant is shortly stalked; rather large arranged in opposite pair bracts short acute, calyx is tubular and deeply cut into 2 lips. Corolla has a short tube it is also strongly 2 lipped. The upper lip is cut into two segments. The stamens are filamentous [4].

It is native of Mediterranean areas of new East and Europe [27]. It is abundantly found in North Africa, Madeira and Canary Islands. In South France and North Italy the wild plant is gathered for use [5]. This plant showed good adaptability in cold and dry areas [2]. This plant is cultivated in all countries as an ornamental and medicinal plant [27]. It is aromatic and seasoning plant due to which it is used in cosmetic and perfume industries [20]. It is also used as food spices [23]. And also used as a flavoring agents [8].

About $80 \%$ of the world population uses the medicinal plants for the health needs. The inter-relationship among plants, man and drugs derived from the plants which are describing the history of mankind. Plants are the great source of medicines. In plants different phytochemicals were present which are active against different diseases [31]. Plants contain different chemical compounds called secondary metabolites are involved in the growth and developments of plants. Some important secondary metabolites are alkaloids, terpenes, and phenolic compounds [41]. Plants contain different anti-oxidant compounds including phenolic compounds like phenol acid, flavinoids, tannins etc [25], [34]. Rosemary is a medicinal plant and it is used in many ways as a medicinal herb such as it improves the blood circulation [20]. The extract of rosemary relaxes the smooth muscles [14]. The volatile oil of Rosemary is a powerful growth 
stimulator. The volatile oil of Rosemary with the combination of other substances is used for the growth of hairs because it promotes the growth of hairs [5]. It has a strong aromatic odour and bitterish taste [24]. It was used in cosmetics and perfume industries [17]. It is commonly used as flavoring agent [18]. The volatile oil of rosemary was a powerful growth stimulator [5].

Different medicinal properties are associated with the Rosemary such as antibacterial, antiviral activity, antitumor activity, due to these activities it is traditionally used medicinally [8], [39].

The plant contains different phyto chemicals such as flavinoids, phenols, volatile oil, terpenoids, caffic, rosemarinic, labiaticacids. The volatile oil contains different components composed of mainly monoterpenes and hydrocarbons which include alpha and beta pinenes, camphene and limonine. Some natural pigments were reported in this plant which is capsaicin and curcumin. Due to which this plant as a great value in medicines, aromatic and as an ornamental plant [8], [29].

Due to the presence of phytochemical compounds different medicinal properties are associated with this plant including antibacterial, antiviral, anti-tumor and antioxidant activities [43]. The extracts of rosemary contain bioactive properties such as phenolic compound which inhibit the growth of gram negative and gram positive bacteria [32]. Rosemary oil has an effective antimicrobial agent it inhibit the growth of molds and many types of bacteria. Carnosolic acid which was present in Rosemary had activity against human immunodeficiency virus type 1 (HIV-1) [18].

Escherichia coli are gram negative bacteria and are a symbiotic bacillus of colon of human beings and vertebrates. This bacterium is easy to grow in the artificial medium at $37^{\circ} \mathrm{c}$ under optimal conditions it divides after every 20 minutes [32].

\section{Material and methods}

Plant material was collected from Sardar Bahadur Khan Women's University Quetta botanical garden (botany department) on $26^{\text {th }}$ of March 2011. Plant material was dried for a week at room temperature and grained. The material was used for different phytochemical tests and antibacterial activity.

For the determination of phytochemistry $25 \mathrm{~g}$ of dried powder of plant material was mixed in $100 \mathrm{ml}$ of methanol and kept for 24 hours then filtered [9], [15], [22], [38].

\subsection{Antibacterial activity of Rosemarinus officinalis}

The experiment was conducted to determine the antibacterial activity of the extracts of Rosemarinus officianalis against E. coli. For this purpose the stem, leaves and flowers of Rosemarinus officianalis collected from SBK Women's University Quetta were used. The following steps were employed during the laboratory work.

The key step for the successful determination of antibacterial activity of an organism is sterilization. Sterilization was followed by two methods: dry and wet sterilization. All The glassware (Petri-plates) were covered with aluminium foil and then kept into the Oven at $90^{\circ} \mathrm{C}$ for two hours.

\subsubsection{Preparation of extracts}

a) $\quad 0.5 \mathrm{gm}$ flower extracts of Rosemarinus officianalis for 24 and $48 \mathrm{hrs}$ :

Weight four samples of $0.5 \mathrm{gm}$ of flower powder and put it separately into four $100 \mathrm{ml}$ conical flasks and mark them as $24 \mathrm{hrs}$ and $48 \mathrm{hrs}$. Add $100 \mathrm{ml}$ distilled water in two flasks and $100 \mathrm{ml}$ of Methanol in two flasks shake it well and leave it for $24 \mathrm{hrs}$ and $48 \mathrm{hrs}$. After the completion of time filter the solution and soak the Watmann's filter paper discs into the filtrate.

b) 1 gm flower extract of Rosemarinus officianalis for 24 and $48 \mathrm{hrs}$ :

Weight four samples of $1 \mathrm{gm}$ of flower powder and put it separately into four $100 \mathrm{ml}$ conical flasks and mark them as 24 hrs and $48 \mathrm{hrs}$. Add $100 \mathrm{ml}$ distilled water in two flasks and $100 \mathrm{ml}$ of Methanol in two flasks shake it well and leave it for $24 \mathrm{hrs}$ and $48 \mathrm{hrs}$. After the completion of time filter the solution and soak the Watmann's filter paper discs into the filtrate.

c) $1.5 \mathrm{gm}$ flower extract of Rosemarinus officianalis for 24 and $48 \mathrm{hrs}$ :

Weight four samples of $1.5 \mathrm{gm}$ of flower powder and put it separately into four $100 \mathrm{ml}$ conical flasks and mark them as $24 \mathrm{hrs}$ and $48 \mathrm{hrs}$. Add $100 \mathrm{ml}$ distilled water in two flasks and $100 \mathrm{ml}$ of Methanol in two flasks shake it well and leave it for $24 \mathrm{hrs}$ and $48 \mathrm{hrs}$. After the completion of time filter the solution and soak the Watmann's filter paper discs into the filtrate.

d) $\quad 0.5 \mathrm{gm}$ leaves extract of Rosemarinus officianalis for $24 \mathrm{hrs}$ and $48 \mathrm{hrs:}$

Weight four samples of $0.5 \mathrm{gm}$ of leaf powder and put it separately into four $100 \mathrm{ml}$ conical flasks and mark them as 24 hrs and $48 \mathrm{hrs}$. Add $100 \mathrm{ml}$ distilled water in two flasks and $100 \mathrm{ml}$ of Methanol in two flasks shake it well and leave it for $24 \mathrm{hrs}$ and $48 \mathrm{hrs}$. After the completion of time filter the solution and soak the Watmann's filter paper discs into the filtrate.

e) $1 \mathrm{gm}$ leaves extract of Rosemarinusofficianalis for $24 \mathrm{hrs}$ and $48 \mathrm{hrs}$ : 
Weight four samples of $1 \mathrm{gm}$ of leaf powder and put it separately into four $100 \mathrm{ml}$ conical flasks and mark them as 24 hrs and $48 \mathrm{hrs}$. Add $100 \mathrm{ml}$ distilled water in two flasks and $100 \mathrm{ml}$ of Methanol in two flasks shake it well and leave it for $24 \mathrm{hrs}$ and $48 \mathrm{hrs}$. After the completion of time filter the solution and soak the Watmann's filter paper discs into the filtrate.

f) $1.5 \mathrm{gm}$ leaves extracts of Rosemarinus officianalis for $24 \mathrm{hrs}$ and $48 \mathrm{hrs}$ :

Weight four samples of $1.5 \mathrm{gm}$ of leaf powder and put it separately into four $100 \mathrm{ml}$ conical flasks and mark them as 24 hrs and $48 \mathrm{hrs}$. Add $100 \mathrm{ml}$ distilled water in two flasks and $100 \mathrm{ml}$ of Methanol in two flasks shake it well and leave it for $24 \mathrm{hrs}$ and $48 \mathrm{hrs}$. After the completion of time filter the solution and soak the Watmann's filter paper discs into the filtrate.

g) $\quad 0.5 \mathrm{gm}$ stem extracts of Rosemarinus officianalis for $24 \mathrm{hrs}$ and $48 \mathrm{hrs}$ :

Weight four samples of $0.5 \mathrm{gm}$ of stem powder and put it separately into four $100 \mathrm{ml}$ conical flasks and mark them as $24 \mathrm{hrs}$ and $48 \mathrm{hrs}$. Add $100 \mathrm{ml}$ distilled water in two flasks and $100 \mathrm{ml}$ of Methanol in two flasks shake it well and leave it for $24 \mathrm{hrs}$ and $48 \mathrm{hrs}$. After the completion of time filter the solution and soak the Watmann's filter paper discs into the filtrate.

h) $1 \mathrm{gm}$ stem extracts of Rosemarinus officianalis for $24 \mathrm{hrs}$ and $48 \mathrm{hrs:}$

Weight four samples of $1 \mathrm{gm}$ of stem powder and put it separately into four $100 \mathrm{ml}$ conical flasks and mark them as 24 hrs and $48 \mathrm{hrs}$. Add $100 \mathrm{ml}$ distilled water in two flasks and $100 \mathrm{ml}$ of Methanol in two flasks shake it well and leave it for $24 \mathrm{hrs}$ and $48 \mathrm{hrs}$. After the completion of time filter the solution and soak the Watmann's filter paper discs into the filtrate.

i) $\quad 1.5 \mathrm{gm}$ stem extracts of Rosemarinus officianalis for $24 \mathrm{hrs}$ and $48 \mathrm{hrs}$ :

Weight four samples of $1.5 \mathrm{gm}$ of stem powder and put it separately into four $100 \mathrm{ml}$ conical flasks and mark them as $24 \mathrm{hrs}$ and $48 \mathrm{hrs}$. Add $100 \mathrm{ml}$ distilled water in two flasks and $100 \mathrm{ml}$ of Methanol in two flasks shake it well and leave it for $24 \mathrm{hrs}$ and $48 \mathrm{hrs}$. After the completion of time filter the solution and soak the Watmann's filter paper discs into the filtrate.

\subsubsection{Preperation of solid medium of agar}

$28 \mathrm{gm}$ of agar nutrient was dissolved in $1000 \mathrm{ml}$ of distilled water. Then the solution was kept on hot plate for some time. Than autoclaved for 45 minutes.

\subsubsection{Agar in petri-plates}

The prepared agar was poured in the Petri plates in front of flame under Laminar flow. Before use the floor of Laminar flow was wiped with $70 \%$ ethanol. After pouring the Petri dishes were kept in the Incubator for 24 hrs in inverted position.

\subsubsection{Preparation of filter paper discs}

Watmann's filter paper was used to prepare filter paper discs. Several discs were made with the help of punching machine. The discs were soaked in the filtrates and then placed in the Petri dishes.

\subsubsection{Inoculation of E.coli in the petri-plates}

Under the Laminar flow in front of flame inoculate the E. coli in the medium. With the help of inoculating loop the colonies of E. coli were mixed in the distilled water and then with the help of cotton transferred into the Petri-plates. At the same time filter paper discs soaked into the solution were also placed into the Petri-plates.

\subsection{Phytochemical screening}

a) Test for reducing sugar:

$0.5 \mathrm{ml}$ of plant extract was mixed with $5 \mathrm{ml}$ of boiling Fehling solution (A and B) in a test tube.

Fehling solution A:

Take 6.93 $\mathrm{g} \mathrm{CuSO}_{4}$ and dissolve in $100 \mathrm{ml}$ water.

Fehling solution B:

Take 34.6g KNaCu$+10 \mathrm{~g} \mathrm{NaOH}$ and dissolve in $100 \mathrm{ml}$ water.

b) Test for flavinoids:

$0.5 \mathrm{ml}$ plant extract was added with $5 \mathrm{ml}$ of water, $5 \mathrm{ml}$ of dilute ammonia and $1 \mathrm{ml}$ of conc.H2SO4.

c) Test for saponins:

$0.5 \mathrm{ml}$ plant extract was added with $5 \mathrm{ml}$ of water in a test tube and shake it vigoursly. A stable forthning was formed then add few drops of olive oil and shake. An emulsion was formed.

d) Test for terpenoids: 
$0.5 \mathrm{ml}$ of plant extract was added with $2 \mathrm{ml}$ of chloroform and $3 \mathrm{ml}$ of conc. H2SO4.

e) Test for tannins:

$0.5 \mathrm{ml}$ of plant extract was boiled with $10 \mathrm{ml}$ of water then filtered. Few drops of $0.1 \%$ ferric chloride were added.

\section{Results}

\subsection{Antibacterial activity of Rosemarinus officinalis}

This study was conducted to analyze the antibacterial activity of the aqueous and methanolic extracts of Rosemarinus officinalis against E. coli. The results were:

a) $\quad 0.5 \mathrm{gm}$ leaves aqueous extract of Rosemarinus officinalisfor $24 \mathrm{hrs}$ and $48 \mathrm{hrs:}$

It was observed that when $0.5 \mathrm{gm}$ aqueous leaf extract of Rosemarinus officinalis was kept for 24 and 48 hrs, it exhibit high value of mean inhibition in $48 \mathrm{hrs}(11.8 \mathrm{~mm})$ as compared to $24 \mathrm{hrs}$ extract $(11.4 \mathrm{~mm})$.

b) $\quad 0.5 \mathrm{gm}$ leaves methanolic extracts of Rosemarinus officinalis for $24 \mathrm{hrs}$ and $48 \mathrm{hrs}$

The methanolic leaves extract kept for $24 \mathrm{hrs}$ and $48 \mathrm{hrs}$ showed the high mean of inhibition in 48 hrs extract that was $17.2 \mathrm{~mm}$ as compared to $24 \mathrm{hrs}$ extract $14.6 \mathrm{~mm}$.

c) $1 \mathrm{gm}$ leaves aqueous extract of Rosemarinus officinalisfor $24 \mathrm{hrs}$ and $48 \mathrm{hrs}$ :

For $1 \mathrm{gm}$ of aqueous leave extracts of Rosemarinus officinalis the high value of inhibition was found in 24 hrs extract $(12.8 \mathrm{~mm})$ while in $48 \mathrm{hrs}$ extract it was $(12 \mathrm{~mm})$.

d) $1 \mathrm{gm}$ leaves methanolic extracts of Rosemarinus officinalisfor $24 \mathrm{hrs}$ and $48 \mathrm{hrs:}$

For1gm methanolic extracts of leaves the high mean value of inhibition was showed by $24 \mathrm{hrs}$ extract $(22.8 \mathrm{~mm})$ and for $48 \mathrm{hrs}$ extract it was $(13.6 \mathrm{~mm})$.

e) $1.5 \mathrm{gm}$ leaves aqueous extracts of Rosemarinus officinalisfor $24 \mathrm{hrs}$ and $48 \mathrm{hrs}$ :

$1.5 \mathrm{gm}$ aqueous leaf extracts of Rosemarinus officinalis kept for $24 \mathrm{hrs}$ and $48 \mathrm{hrs}$, it exhibit high value of mean inhibition in $24 \mathrm{hrs}$ extract $(14.4 \mathrm{~mm})$ and for $48 \mathrm{hrs}$ extract it was $(13 \mathrm{~mm})$.

f) $1.5 \mathrm{gm}$ methanolic leaves extracts of Rosemarinus officinalisfor $24 \mathrm{hrs}$ and $48 \mathrm{hrs:}$

It was observed that when $1.5 \mathrm{gm}$ of methanolic leaves extracts of Rosemarinus officinalis kept for $24 \mathrm{hrs}$ and $48 \mathrm{hrs}$, it exhibit high value of mean inhibition in $48 \mathrm{hrs}$ extract $(28.8 \mathrm{~mm})$ as compare to $24 \mathrm{hrs}$ extract $(23.6 \mathrm{~mm})$.

g) $\quad 0.5 \mathrm{gm}$ stem aqueous extract of Rosemarinus officinalisfor $24 \mathrm{hrs}$ and $48 \mathrm{hrs:}$

It was observed that when $0.5 \mathrm{gm}$ aqueous stem extract of Rosemarinus officinalis was kept for 24 and 48 hrs, it exhibit highest value of mean inhibition in $24 \mathrm{hrs}(16.8 \mathrm{~mm})$ as compared to $48 \mathrm{hrs}$ extract $(10 \mathrm{~mm})$.

h) $\quad 0.5 \mathrm{gm}$ stems methanolic extracts of Rosemarinus officinalisfor $24 \mathrm{hrs}$ and $48 \mathrm{hrs}$ :

The methanolic stem extract kept for $24 \mathrm{hrs}$ and $48 \mathrm{hrs}$ showed the high mean of inhibition in 48 hrs extract that was $11.8 \mathrm{~mm}$ as compared to $24 \mathrm{hrs}$ extract $10.4 \mathrm{~mm}$.

i) $1 \mathrm{gm}$ stem aqueous extract of Rosemarinus officinalisfor $24 \mathrm{hrs}$ and $48 \mathrm{hrs}$ :

For $1 \mathrm{gm}$ of aqueous stem extracts of Rosemarinus officinalis the high value of inhibition was found in 24 hrs extract $(12.2 \mathrm{~mm})$ while in $48 \mathrm{hrs}$ extract it was $(12 \mathrm{~mm})$.

j) $1 \mathrm{gm}$ stem methanolic extracts of Rosemarinus officinalisfor $24 \mathrm{hrs}$ and $48 \mathrm{hrs:}$

For1gm methanolic extracts of stem the high mean value of inhibition was showed by 48 hrs extract (9.4mm) and for 24 hrs extract it was $(8.8 \mathrm{~mm})$.

k) $\quad 1.5 \mathrm{gm}$ stem aqueous extracts of Rosemarinus officinalisfor $24 \mathrm{hrs}$ and $48 \mathrm{hrs}$ :

$1.5 \mathrm{gm}$ aqueous stem extracts of Rosemarinus officinalis kept for $24 \mathrm{hrs}$ and $48 \mathrm{hrs}$, it exhibit high value of mean inhibition in $48 \mathrm{hrs}$ extract $(17.6 \mathrm{~mm})$ and for $24 \mathrm{hrs}$ extract it was $(12.6 \mathrm{~mm})$.

1) $1.5 \mathrm{gm}$ methanolic stem extracts of Rosemarinus officinalisfor $24 \mathrm{hrs}$ and $48 \mathrm{hrs}$ :

It was observed that when $1.5 \mathrm{gm}$ of methanolic stem extracts of Rosemarinus officinalis kept for $24 \mathrm{hrs}$ and $48 \mathrm{hrs}$, it exhibit high value of mean inhibition in $24 \mathrm{hrs}$ extract (13.4mm) as compare to $48 \mathrm{hrs}$ extract $(8.6 \mathrm{~mm})$.

m) $\quad 0.5 \mathrm{gm}$ flower aqueous extract of Rosemarinus officinalis for $24 \mathrm{hrs}$ and $48 \mathrm{hrs:}$

It was observed that when $0.5 \mathrm{gm}$ of methanolic flower extracts of Rosemarinus officinalis kept for $24 \mathrm{hrs}$ and $48 \mathrm{hrs}$, it exhibit high value of mean inhibition in $24 \mathrm{hrs}$ extract $(15.4 \mathrm{~mm})$ as compare to $48 \mathrm{hrs}$ extract $(10 \mathrm{~mm})$.

n) $\quad 0.5 \mathrm{gm}$ flower methanolic extracts of Rosemarinus officinalis for $24 \mathrm{hrs}$ and $48 \mathrm{hrs}$ :

The methanolic flower extract of $0.5 \mathrm{gm}$, kept for $24 \mathrm{hrs}$ and $48 \mathrm{hrs}$ showed the high mean of inhibition in $48 \mathrm{hrs}$ extract that was $15.4 \mathrm{~mm}$ as compared to $24 \mathrm{hrs}$ extract $13.4 \mathrm{~mm}$.

o) $1 \mathrm{gm}$ flower aqueous extracts of Rosemarinus officinalis for $24 \mathrm{hrs}$ and $48 \mathrm{hrs}$ : It was observed that when $1 \mathrm{gm}$ of methanolic flower extracts of Rosemarinus officinalis kept for $24 \mathrm{hrs}$ and $48 \mathrm{hrs}$, it exhibit high value of mean inhibition in $24 \mathrm{hrs}$ extract $(15.8 \mathrm{~mm})$ as compare to $48 \mathrm{hrs}$ extract $(12.2 \mathrm{~mm})$.

p) $1 \mathrm{gm}$ flower methanolic extracts of Rosemarinus officinalis for $24 \mathrm{hrs}$ and $48 \mathrm{hrs}$ :

The methanolic flower extract of $1 \mathrm{gm}$, kept for $24 \mathrm{hrs}$ and $48 \mathrm{hrs}$ showed the high mean of inhibition in $48 \mathrm{hrs}$ extract that was $25.4 \mathrm{~mm}$ as compared to $24 \mathrm{hrs}$ extract $19.4 \mathrm{~mm}$.

q) $1.5 \mathrm{gm}$ flower aqueous extracts of Rosemarinus officinalis for $24 \mathrm{hrs}$ and $48 \mathrm{hrs}$ :

It was observed that when $1.5 \mathrm{gm}$ of methanolic flower extracts of Rosemarinus officinalis kept for $24 \mathrm{hrs}$ and $48 \mathrm{hrs}$, it exhibit high value of mean inhibition in $24 \mathrm{hrs}$ extract $(13.2 \mathrm{~mm})$ as compare to $48 \mathrm{hrs}$ extract $(12.8 \mathrm{~mm})$. 
r) $\quad 1.5 \mathrm{gm}$ flower methanolic extracts of Rosemarinus officinalis for $24 \mathrm{hrs}$ and $48 \mathrm{hrs}$ :

$1.5 \mathrm{gm}$ methanolic flower extracts of Rosemarinus officinalis kept for $24 \mathrm{hrs}$ and $48 \mathrm{hrs}$, it exhibit high value of mean inhibition in $48 \mathrm{hrs}$ extract $(25 \mathrm{~mm})$ and for $24 \mathrm{hrs}$ extract it was $(15.2 \mathrm{~mm})$.

Table 1: Showing Mean and Standard Error of Leaves Aqueous and Methanolic Extracts of Rosemarinus Officinalis $24 \mathrm{Hours}(0.5 \mathrm{~g}, 1 \mathrm{~g}$ and $1.5 \mathrm{~g}$ ) Against E. coli

\begin{tabular}{lll}
\hline Concentration In Grams. & Water & Methanol \\
\hline & $\overline{\mathrm{x}} \pm \partial$ & $\overline{\mathrm{x}} \pm \partial$ \\
\cline { 2 - 3 } $0.5 \mathrm{~g}$ & $11.4 \pm 2.33$ & $14.6 \pm 1.496$ \\
$1 \mathrm{~g}$ & $12.8 \pm 3.682$ & $22.8 \pm 3.969$ \\
$1.5 \mathrm{~g}$ & $14.4 \pm 2.33$ & $23.6 \pm 2.416$ \\
\hline
\end{tabular}

Table 2: Showing Mean and Standard Error of Leaves Aqueous and Methanolic Extracts of Rosemarinus Officinalis $48 \mathrm{Hours}(0.5 \mathrm{~g}$, $1 \mathrm{~g}$ and $1.5 \mathrm{~g})$ Against E. coli:

\begin{tabular}{lll}
\hline Concentration In Grams. & Water & Methanol \\
\hline & $\overline{\mathrm{x}} \pm \partial \pm \partial$ & $\overline{\mathrm{x}}$ \\
\cline { 2 - 3 } $0.5 \mathrm{~g}$ & $11.8 \pm 1.6$ & $17.2 \pm 3.815$ \\
$1 \mathrm{~g}$ & $12 \pm 2.280$ & $13.6 \pm 3.498$ \\
$1.5 \mathrm{~g}$ & $13 \pm 3.464$ & $28.8 \pm 4.261$ \\
\hline
\end{tabular}

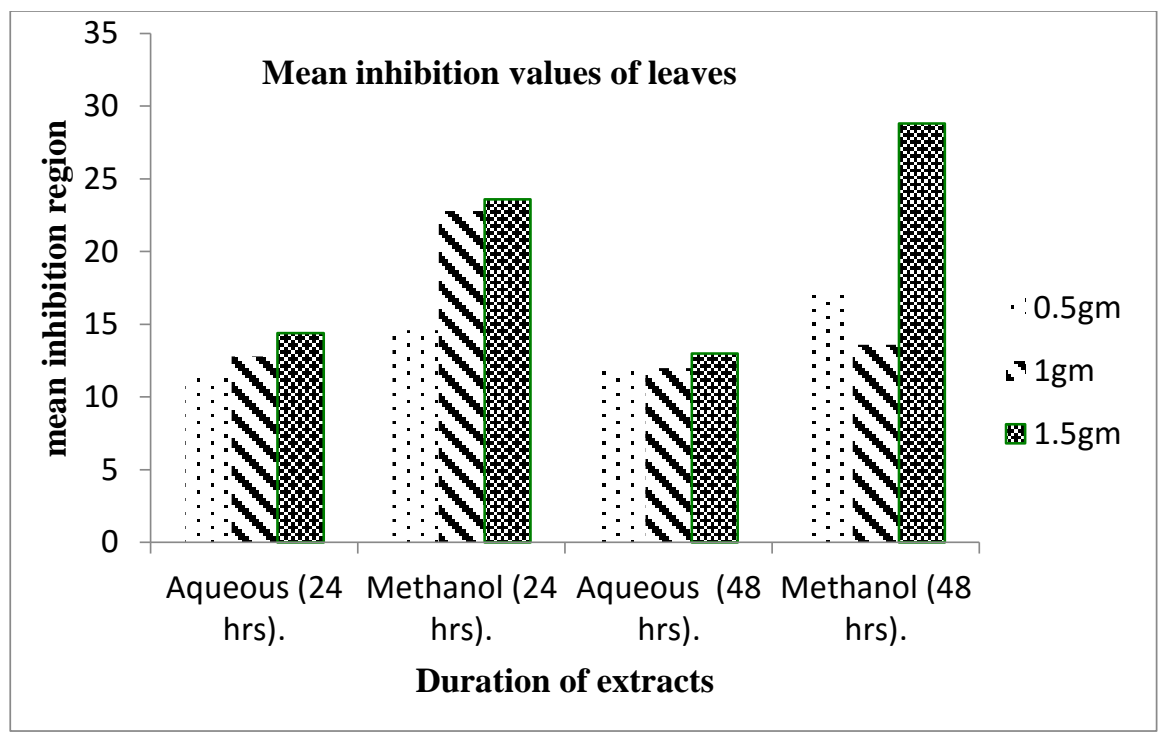

Fig.1: Showing the mean inhibition region of the extracts of leaves of Rosemarinus officinalis.

Table 3: Showing Mean and Standard Error of Stem Aqueous and Methanolic Extracts of Rosemarinus Officinalis 24 Hours (0.5g, 1g and 1.5g) Against E. coli

\begin{tabular}{lll}
\hline Concentration In Grams. & Water & Methanol \\
\hline & $\overline{\mathrm{x}} \pm \partial$ & $\overline{\mathrm{x}} \pm \partial$ \\
\cline { 2 - 3 } $1 \mathrm{~g}$ & $16.8 \pm 2.315$ & $10.4 \pm 2.24$ \\
$\mathrm{~g}$ & $12.2 \pm 1.939$ & $8.8 \pm 1.939$ \\
$1.5 \mathrm{~g}$ & $12.6 \pm 1.362$ & $13.4 \pm 1.624$ \\
\hline
\end{tabular}

Table 4: Showing Mean and Standard Error of Stem Aqueous and Methanolic Extracts of Rosemarinus Officinalis 48 Hours $(0.5 \mathrm{~g}, 1 \mathrm{~g}$ and $1.5 \mathrm{~g})$ Against E. coli

\begin{tabular}{lll}
\hline Concentration In Grams. & Water & Methanol \\
\hline & $\overline{\mathrm{x}} \pm \partial$ & $\overline{\mathrm{x}} \pm \partial$ \\
\cline { 2 - 3 } $0.5 \mathrm{~g}$ & $10 \pm 1.095$ & $11.8 \pm 1.833$ \\
$\mathrm{~g}$ & $12 \pm 2.280$ & $9.4 \pm 0.8$ \\
$1.5 \mathrm{~g}$ & $17.6 \pm 4.029$ & $8.6 \pm 1.854$ \\
\hline
\end{tabular}




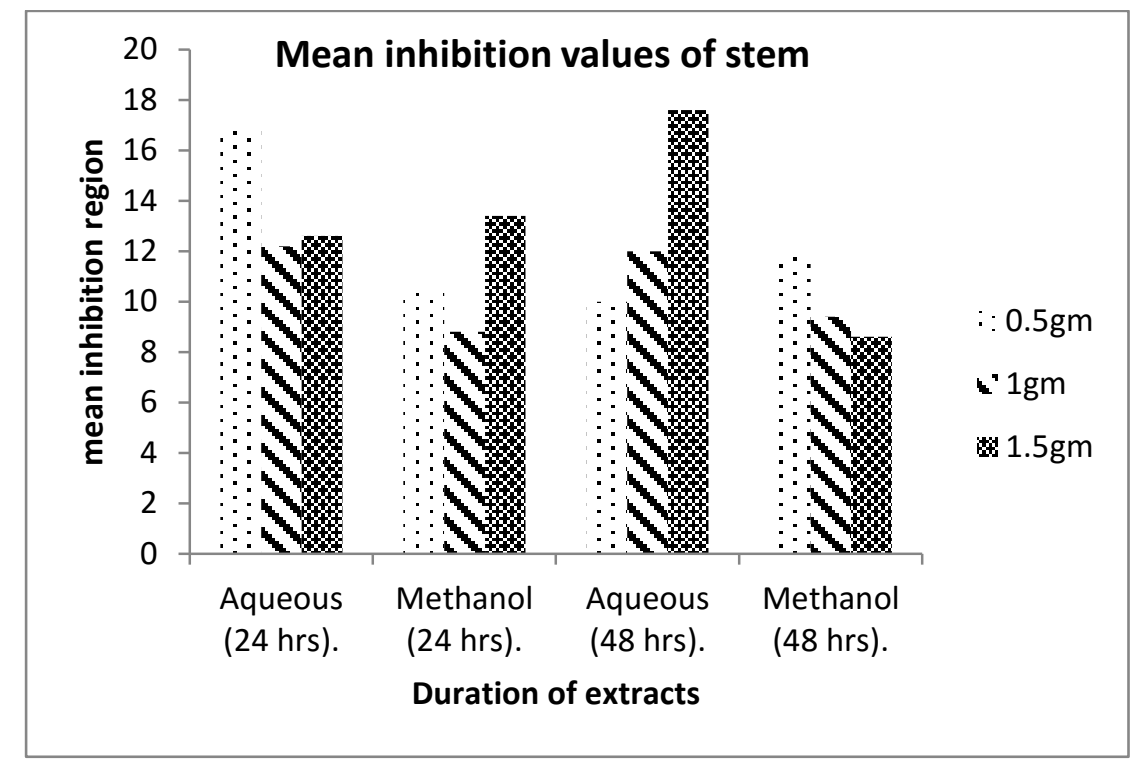

Fig.2: Showing the mean inhibition value of the extracts of stem of Rosemarinus officinalis.

Table 5: Showing Mean and Standard Error of Flower Aqueous and Methanolic Extracts of Rosemarinus Officinalis $24 \mathrm{Hours}(0.5 \mathrm{~g}$, $1 \mathrm{~g}$ and $1.5 \mathrm{~g}$ ) Against E. coli

\begin{tabular}{|c|c|c|}
\hline Concentration In Grams. & Water & Methanol \\
\hline & $\overline{\mathrm{x}} \pm \partial$ & $\overline{\mathrm{x}} \pm \partial$ \\
\hline 0.5 & $15.4 \pm 3.555$ & $13.4 \pm 2.332$ \\
\hline 1 & $15.8 \pm 2.993$ & $19.4 \pm 5.748$ \\
\hline 1.5 & $13.2 \pm 1.166$ & $15.2 \pm 3.762$ \\
\hline
\end{tabular}

Table 6: Showing Mean and Standard Error of Flower Aqueous and Methanolic Extracts of Rosemarinus Officinalis $48 \mathrm{Hours}(0.5 \mathrm{~g}$, $1 \mathrm{~g}$ and $1.5 \mathrm{~g})$ Against E. coli

\begin{tabular}{|c|c|c|}
\hline Concentration In Grams. & Water & Methanol \\
\hline & $\overline{\mathrm{x}} \pm \partial$ & $\overline{\mathrm{x}} \pm \partial$ \\
\hline 0.5 & $10 \pm 1.673$ & $15.4 \pm 5.388$ \\
\hline 1 & $12.2 \pm 1.720$ & $25.4 \pm 2.416$ \\
\hline 1.5 & $12.8 \pm 2.315$ & $25 \pm 4.816$ \\
\hline
\end{tabular}

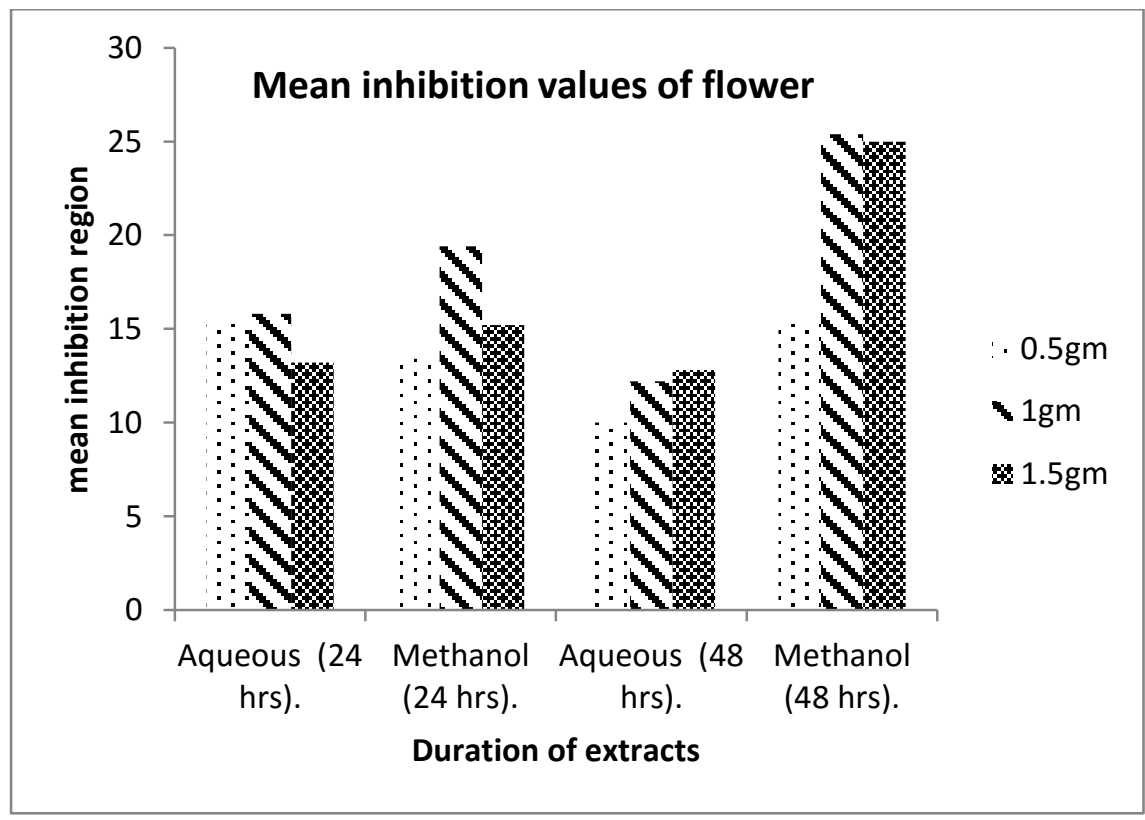

Fig.3: Showing the mean inhibition value of the extracts of flowers of Rosemarinus officinalis. 


\subsection{Phytochemical analysis of Rosemarinus officinalis}

\begin{tabular}{|c|c|c|c|c|c|}
\hline TESTS. & PROCEDURE. & LEAVES. & FLOWERS. & STEM. & RESULT. \\
\hline $\begin{array}{l}\text { Reducing } \\
\text { sugar. }\end{array}$ & $\begin{array}{l}0.5 \mathrm{ml} \text { plant extract } \\
+ \text { Fehling solution } \mathrm{A} \text { and } \\
\mathrm{B}+\text { boiled. }\end{array}$ & $\begin{array}{l}+ \\
\text { Yellowish green } \\
\text { color appeared. }\end{array}$ & $\begin{array}{l}+ \\
\text { Dark green color } \\
\text { appeared. }\end{array}$ & $\begin{array}{l}+ \\
\text { Dark green } \\
\text { color } \\
\text { appeared. }\end{array}$ & $\begin{array}{l}\text { Low conc. in } \\
\text { leaves while high } \\
\text { in stem and } \\
\text { flowers. }\end{array}$ \\
\hline Terpenoid. & $\begin{array}{l}0.5 \mathrm{ml} \text { plant extracts } \\
+2 \mathrm{ml} \text { chloroform }+3 \mathrm{ml} \\
\text { conc. } \mathrm{H} 2 \mathrm{SO} 4 .\end{array}$ & $\begin{array}{l}+ \\
\text { Reddish brown } \\
\text { color appeared. }\end{array}$ & $\begin{array}{l}+ \\
\text { Reddish brown } \\
\text { color appeared in } \\
\text { the form of rings. }\end{array}$ & $\begin{array}{l}+ \\
\text { Reddish } \\
\text { brown color } \\
\text { appeared. }\end{array}$ & $\begin{array}{l}\text { High conc. In } \\
\text { flowers while low } \\
\text { in stem and } \\
\text { leaves. }\end{array}$ \\
\hline Flavinoid. & $\begin{array}{l}0.5 \mathrm{ml} \text { plant extract }+ \\
5 \mathrm{ml} \text { ammonia }+1 \mathrm{ml} \\
\text { conc. Sulphioric acid. }\end{array}$ & $\begin{array}{l}+ \\
\text { Yellow color } \\
\text { appeared. }\end{array}$ & $\bar{N}$ No reaction. & $\begin{array}{l}+ \\
\text { Light yellow } \\
\text { color } \\
\text { appeared. }\end{array}$ & $\begin{array}{l}\text { Absent in flowers } \\
\text { while high conc. } \\
\text { in stem. }\end{array}$ \\
\hline Tannin. & $\begin{array}{l}0.5 \mathrm{ml} \text { plant extract }+ \\
10 \mathrm{ml} \text { water }+ \text { boiled }+0.1 \\
\% \text { ferric chloride. }\end{array}$ & 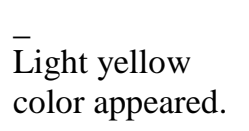 & $\begin{array}{l}\text { Light yellow color } \\
\text { appeared. }\end{array}$ & $\overline{\text { No reaction. }}$ & Absent. \\
\hline Saponins. & $\begin{array}{l}0.5 \mathrm{ml} \text { plant extract+ } \\
5 \mathrm{ml} \text { water+ } 3 \text { drops of } \\
\text { olive oil. }\end{array}$ & $\begin{array}{l}+ \\
\text { Oil emulsion is } \\
\text { formed on the } \\
\text { top of solution. }\end{array}$ & $\begin{array}{l}+ \\
\text { Oil emulsion is } \\
\text { formed. }\end{array}$ & $\begin{array}{l}+ \\
\text { Oil emulsion } \\
\text { is formed. }\end{array}$ & $\begin{array}{l}\text { High conc. in } \\
\text { leaves while low } \\
\text { in stem and } \\
\text { flower. }\end{array}$ \\
\hline
\end{tabular}

$(+)=$ Present

$(-)=$ Absent

\section{Discussion}

The Rosemarinus officinalis was investigated for its phytochemical constitution and anti-bacterial activity. The plant material was collected from Sardar Bahadur Khan Women's University Quetta. Stem, leaves and flowers of Rosemarinus officinalis were used for this purpose. Different phytochemical compounds were found in different concentrations. Flavinoids, phenols, volatile oil, terpenoids and tennic acid were the principle constituents of Rosemary. It showed good inhibitory effects against E. coli [21].

The in vitro antibacterial activity of methanolic and aqueous extracts of Rosemary at different concentrations was done against E. coli.

The methanolic extracts of leaves $1.5 \mathrm{gm}$ showed highest value of mean inhibition zone that was 28.6mm [10]. Our results agree with the findings of [16].

The second highest inhibition zone was observed in the methanoilc extracts of flower kept for 48 hours with the concentration of $1 \mathrm{gm}(25.4 \pm 2.416 \mathrm{~mm})$.

In the aqueous extracts the highest inhibition zone $(17.6 \pm 4.029 \mathrm{~mm})$ was observed in the stem with the concentration of $1.5 \mathrm{gm}$ for $48 \mathrm{hrs}$ extract [34].

The test of reducing sugar was done, yellowish green color appeared which was changed in dark green color and indicates the presence of reducing sugar [7].

Terpenoids were present in high concentration in all the parts including flower, leaves and the stem. In the test of flower 3 rings of different colors appeared on the test tube. The top ring was brown in color, in middle it was green and the upper ring was brown colored. These results agree with the work of [36], [6]

The test of flavinods showed different concentrations in the leaves and stem while it was absent in the flowers. In the stem it was present in high concentration while in the leaves it was found in medium concentration. Aeyni \& Yahya reported the same results [6].

Tannins were absent in all the parts of Rosemarinus officinalis.

Saponins were present in high concentration in the leaves, stem and flower. An oil emulsion was formed on the top of the solution which indicates the presence of saponins. Our results agree with the results of [1].

The presence of these phyto-chemical compounds indicate that various medicinal properties were associated with Rosemary which supports the traditional and medicinal uses of this plant [3].

\section{Conclusion}

Rosemarinus officinalis was analyzed for its anti-bacterial activity against E. coli and phytochemical composition. The plant material was collected from Sardar Bahadur Khan Women's University Quetta. To investigate the anti-bacterial activity of Rosemarinus officinalis aqueous and methanolic extracts of the flowers, leaves and stem were prepared and kept for 24 hours and 48 hours with the concentration of $0.5 \mathrm{gm}, 1 \mathrm{gm}$ and $1.5 \mathrm{gm}$. 
Highest concentrations of extracts revealed more inhibition against E. coli then the lower concentrations.

Highest inhibition zone was observed in the leaves methanolic extracts of $1.5 \mathrm{gm}$ kept for 48 hours (i-e. $28.8 \pm$ $4.261 \mathrm{~mm}$ ). The second highest inhibition zone was observed in the flowers methanolic extract of 48 hours with the concentration $1 \mathrm{gm}$ the mean value was $(25.4 \pm 2.416 \mathrm{~mm})$.In the aqueous extracts the highest inhibition zone was observed in the stem extracts of $1.5 \mathrm{gm}$ kept for 48 hours. The mean value was $(17.6 \pm 4.029 \mathrm{~mm})$.

Different tests including reducing sugar, flavonoids, terpenoids, tannins and saponins were practiced for phytochemical screening. All the tests were positive except tannins. Our results showed best inhibition against E. coli.

\section{References}

[1] Achakzai, A. K. K., P. Achakzai., A. Masood., S. A. Kayani and R. B. Tareen, Response of plant parts and age on the distribution of secondary metabolites on plants found in Quetta. Pak. J. Bot. 41(5): (2009) 2129-2135.

[2] Ahmad, M., A. M. Khan., M. Zafar and S. Sultana, Treatment of common ailments by plant-based remedies among the people of district Attock (Punjab) of Northern Pakistan, Afr. J. Trad.CAM. 4(1): (2007) 112-120.

[3] Ahmad, S., S. Koukab., M. Islam., K. Ahmad., S. Aslam., Aminullah and A. Gill, Germplasm evaluation of medicinal and aromatic plants in Baluchistan. Pak. J. Bot. 40(4): (2008) 1473-1479.

[4] Ali, S. I, Flora of Pakistan. 192 Labiateae. (1990) 26.

[5] Atangwho, I.J., P. E. Ebong., E. U. Eyong., I. O. Williams., M. U. Eteng and G. E. Egbung, Comparative chemical composition of leaves of some ant diabetic medicinal plants. Azadirachta indica, Vernonia amygdalina and Gongronem alatifolium . African journal of biotechnology. 8(18): (2009) 4685-4689.

[6] Ayeni, K. F and S. A. Yahya, Phytochemical screening of three medicinal plants Neem (Azadirachita indica), Hibiscus leaf (Hibiscus rosasinensis) and spear grass leaf (Impereta cylindrical). Continental J. Pharmaceutical sciences, 4: (2010) 47-50.

[7] Ayoola.G.A.,H.Coker.,S.Adesegun.,A.A.Bello.,K.Obaweya.,E.Ezennia,E and T. Atangbayila, Phytochemical screening and antioxidant activities of some selected medicinal plants used for malaria therapy in South Western Nigeria. Tropical journal of pharmaceutical research, 7 : (2008) 1019-1024.

[8] Baydar, H., O. Sagdic., G. Ozkan., and T. Karadogen, Antibacterial activity and composition of essential oils from Origonum, Thymbra and Satureja species with commercial importance in Turkey. Food control. 15: (2004) 169-172. http://dx.doi.org/10.1016/S0956-7135(03)00028-8.

[9] Bibi, Y., S. Nisa., A. Waheed., M. Zia., S. Sarwar., S. Ahmed and M. F. Chaudhary, Evaluation of Viburnum foetens for anticancer and antibacterial potential and phytochemical analysis. African journal of biotechnology. 9(34): (2010) 5611-5615.

[10] Bozin, B., N. Mimica-Dukic., I. Samojilik and E. Jovin, Antimicrobial and anti-oxidant properties of Rosemary and sage (Rosemarinus officinalis and Salvia officinalis L. Lamiaceae) essential oils. Journal of Agriculture and Food Chemistry 55: (2007) $7879-7885$. http://dx.doi.org/10.1021/jf0715323.

[11] Budka, D and N. A.Khan, The effects of Ocimumbacilicum, Thymus vulgaris, and Origanium vulgare essential oils on Bacillus cereus in rice based foods. Euorpean Journal of Biological Sciences 2(1): (2010) 17-20.

[12] Edeoga, H. O., G. Omosun and L. C. Unche, Chemical composition of Hyptis suaveolens and Ocimum gratissimum hybrids from Nigeria. African Journal of Biotechnology. 5: (2006) 892-895.

[13] El-Bastawesy, A. M., R. H. Mohamad and A. A. El-Refai, Chemical and biological evaluation of Rosemary (Rosemarinus officinalis L.) leaves volatile oil and its methanolic extracts. Annual Agric. Sci. 54(20): (2009) 397-415.

[14] Faixova, Z and S. Faix, Biological effects of Rosemary (Rosemarinus officinalis Li.) essential (a review). Folia veterinaria. 52(3-4): (2008) 135-139.

[15] Farrukh, U., H. Shareef., S. Mohammad., S. A. Ali and G. H. Rizwani. 2008. Antibacterial activity of Coccinia grandis L. Pakistan Journal of Botany 40(3): (2008) 1259- 1262.

[16] Hac-Szymanczuk, E., E. Lipinska and M. Stasiuk, The effect of Rosemary preparation on the microbial quality and tbars value of model pork batters. Acta scientiarum Polonorum / Technologia alimentaria 10(2): (2011) 165-174.

[17] Harisarunraj, R., K. Suresh and S. Saravanababu, Evaluation of the chemical composition of Rauwdifasu pentina and Ephedra vulgaris. Advance in Biological research. 3: (2009) 174-178.

[18] Hussain, J., A. L. Khan., N. U. Rehman., Zainullah., F. Khan., S. T. Hussain and Z. K. Shinwari. 2009. Proximate and nutrient investigation of selected medicinal plant species of Pakistan. Pakistan journal of nutrition. 8: (2009) 620-624.

[19] Hussain, J., F. U. Khan, M. Z. Riazullah., I. Khan., M. Zohaib., Imam- ud- din and S. M. Hussain. Nutrient Evaluation and Elemental Analysis of Four selected Medicinal Plants of Khaiber Pakhtoon Khwa, Pakistan. Pakistan Journal of Botany. 43: (2011) 427-434.

[20] Jalacic, S., L. N. Beatovic and A. Vujaosevic, The effect of natural biostimulators and slow disintegrating fertilizers on the quality of rosemary seedlings. Journal of Agricultural sciences.52: (2007) 85-94.

[21] Khafagi, I., A. Dewedar and S. Farouk, In-vitro cytotoxicity and anti-microbial activities of some common essential oils. Egyptain Journal of biology. 2: (2000) 20-27.

[22] Khan, A. S., I. Ilahi., N. Hunar and H. Bibi, Preliminary phytochemical screening of some plants of ethanobotanical importance from district Gilgit, Northern, areas, Pakistan. Pakistan Journal of plant Sciences 15(1): (2009) 15-18.

[23] Kiarostemic, K.H., R. Mohseni and A. Saboor, Biochemical changes of Rosemarinus officianalis under salt stress. Journal of Stress Physiology and Biochemistry. 6: (2010) 114-122.

[24] Kochar, A., m. Nagi and Sachdeva, Proximate composition, available carbohydrates, dietary fiber and anti-nutritional factors of selected traditional medicinal plants. Journal of Human Ecology. (3): (2006) 195-199.

[25] Larson, R. A, Naturally occurring anti-oxidants, Boca Raton, (1997) 189.

[26] Mierici, I.D, Phytochemical study of some active principles with antioxidant action from the Rosemarinus officinalis and Salvia officinalis species. (2009) 79-83.

[27] Mohsenzadeh, M, Evaluation of antibacterial activity of selected Iranian essential oils against Staphylococcus aureus and Escherichia coli in nutrient broth medium. Pakistan journal of biological sciences. 10(20): (2007) 3693-3697.

[28] Muanda, F.N., J. Bouayed., A. Dijilani., C. Yao., R. Soulionani and A. Dicko. Chemical composition and cellular evaluation of antioxidant activity of Desmodium adscendens leaves. Evidence based complementary and alternative medicines (2011).

[29] Mushtaq, A., Q. Rehmatullah., A. Mohammad., A. K. Mir and Z. Mohammad, Traditional herbal remedies used for the treatment of diabetes from district Attock (Pakistan). Pakistan Journal of Botany 41(6): (2009) 2777-2782.

[30] Nasir, E and S. I. Ali, Flora of West Pakistan, National herbarium Agriculture Research Council Rawalpindi (1999).

[31] Nisar, M., S. A. Tariq and I. Ullah, Nutritional levels of Indigofera gerdiana Wall and Crataegus songrica K. Koc., Pakistan Journal of Botany 41(3): (2009) 1359-1361.

[32] Okwu, D and C. Joseph, Evaluation of the chemical composition of two Nigerian medicinal plants. African Journal of Biotechnology. 5(4): (2006) $357-361$ 
[33] Ouwehand, A. C., K. Thhonen., H. Kehunen., S. Peuranen., H. Schulze and N. Rautonen, In vitro effects of essential oils on potential pathogens and beneficial members of the normal microbiota veterinarni Medicina. 5: (2010) 71-78.

[34] Parekh, J and S. V. Chanda, In vitro anti-microbial activity and phytochemical analysis of some Indian medicinal plants. Turkish Journal of Biology 31: (2007) 53-58.

[35] Patel, G., S. Nayak and S. Shrivastava, Physical evaluation and qualitative chemical examination of methanolic extracts of Neriumindicum. Inter Jeurs Trends Sci Tech. 1(2): (2010) 32-36.

[36] Rasool, R., B. A. Ganai., S. Akbar., Z. N. Kamili and A. Masood, Phytochemical screening of Prunella vulgaris L. An important medicinal plant of Pakistan. Pak. J. Pharma. Sci. 23: (2010) 399-402.

[37] Rozman, T and B. Jersek, Antimicrobial activity of Rosemary extracts (Rosemarinus officianalis L.) against different species of Listeria (2009).

[38] Siddique, S., A. Verma., A. A. Rather., F. Jabeen and M. K. Meghvansi, Preliminary phytochemicals analysis of some important medicinal and aromatic plants. Advanced in biological research. 3: (2009) 188-195.

[39] Saikia, L. R and Upadhyaya, Antioxidant activity, phenol and flavinoid content of some less known medicinal plants of Assam. International journal of pharma and bio sciences. 2(2): (2011) 383-388.

[40] Svoboda, K.P and J. B. Hampson, Bioactivity of essential oils of selected temperate aromatic plants. Antibacterial, antioxidant, antiinflammatory and other related pharmacological activities (1999).

[41] Taiz, L and E. Zeiger, Plant physiology. The Benjamin/ Cummings Pub. Co, Inc. 390 Bridge parkway, road city, California 94065. USA (1991).

[42] Uddin, G., T. U. Rehman., M. Irfan., W. Liaqat., M. Qaisar., A. Rauf., G. Mohammad., M. S. Afridi and M. I. Choudary, Phytochemical and biological screening of seeds of Indigofera heteranthiawall. Middle East journal of scientific research. 8(1): (2011) 186-190.

[43] Vaghasiya, Y., R. Dave and S. Chanda. 2011. Phytochemical analysis of some medicinal plants from western region of India. Research journal of Medicinal plants. 5: (2011) 567-57. 